\title{
Simultaneous Detection of Xanthomonas oryzae pv. oryzae and $X$. oryzae pv. oryzicola in Rice Seed Using a Padlock Probe-Based Assay
}

\author{
Yanli Tian, Yuqiang Zhao, Rui Xu, Fengquan Liu, Baishi Hu, and R. R. Walcott
}

First, third, fourth, and fifth authors: College of Plant Protection and Key Laboratory of Integrated Management of Crop Diseases and Pests, Ministry of Education, Nanjing Agricultural University, Nanjing 210095, China; second author: Shanghai Agricultural Technology Extension and Service Center; Shanghai 201103, China; fifth author: National Engineering Research Center for Cucurbits, Changji 831100, China; and sixth author: Department of Plant Pathology, University of Georgia, Athens 30602. Accepted for publication 19 March 2014.

\begin{abstract}
Tian, Y., Zhao, Y., Xu, R., Liu, F., Hu, B., and Walcott, R. R. 2014. Simultaneous selection of Xanthomonas oryzae pv. oryzae and X. oryzae pv. oryzicola in rice seed using a padlock probe-based assay. Phytopathology 104:1130-1137.

Based on 16S-23S internal transcribed spacer ribosomal DNA sequence data, two padlock probes (PLPs), P-Xoo and P-Xoc, were designed and tested to detect Xanthomonas oryzae pv. oryzae and X. oryzae pv. oryzicola, respectively. These PLPs were combined with dot-blot hybridization to detect $X$. oryzae pv. oryzae and $X$. oryzae pv. oryzicola individually in rice seed. Using this technique, a detection sensitivity of $1 \mathrm{pg}$ of $X$. oryzae pv. oryzae genomic DNA was observed. The technique also facilitated the detection of $X$. oryzae pv. oryzae in rice seedlots with $2 \%$ artificially infested seed. With regards to X. oryzae pv. oryzicola a

detection threshold of $1 \mathrm{pg}$ genomic DNA was observed and the pathogen was successful detected in rice seedlots with $0.2 \%$ artificially infested seed. The PLP assays detected $X$. oryzae pv. oryzae and $X$. oryzae pv. oryzicola in $39.3 \%$ (13 of 33) and $21.3 \%$ (10 of 47) of naturally infested commercial rice seedlots, respectively. In contrast, conventional polymerase chain reaction using OSF1/OSR1 and XoocF/XoocR primers sets detected $X$. oryzae pv. oryzae and X. oryzae pv. oryzicola in $9.1 \%$ (3 of 33 ) and $8.5 \%$ ( 4 of 47 ) of the same rice seedlots, respectively. We also detected both pathogens simultaneously in two seedlots, which successfully proved that PLPs (P-Xoo and P-Xoc) combined with reverse dotblot hybridization can be used to simultaneously detect multiple pathogens in naturally infested commercial rice seedlots. This approach has the potential to be an important tool for detecting multiple pathogens in seed and thereby preventing the spread of important pathogens.
\end{abstract}

Bacterial leaf blight (BLB) of rice caused by Xanthomonas oryzae pv. oryzae (20) and bacterial leaf streak (BLS) of rice caused by X. oryzae pv. oryzicola (Xoc) (20) are economically important diseases of rice. BLB is one of the most devastating diseases of rice worldwide and has been reported in Asia, Australia, Latin America, and Africa (16,23). It is particularly problematic in irrigated rice production, causing up to $60 \%$ yield losses in severe epidemics $(21,22)$. BLS has been reported in tropical Asia, parts of West Africa, and northern Australia $(4,15,19,38)$, and 5 to $30 \%$ rice yield losses have been attributed to this disease (28). In 2002, X. oryzae pv. oryzicola was listed on the U.S. Agricultural Bioterrorism Protection Act as a potential bioterrorism agent, necessitating strict biosecurity measures in addition to standard disease management practices (19). Of the two diseases, BLS is less economically important because its damage potential depends on conditions of high moisture and high rates of nitrogen fertilizer $(20,21)$. Nevertheless, under conductive environmental conditions, BLS can be as destructive as BLB (19).

Infested rice seed is an important source of primary inoculum for $X$. oryzae pv. oryzae and X. oryzae pv. oryzicola $(13,25,27)$; therefore, planting pathogen-free seed is critically important for

Corresponding authors: B. Hu; E-mail address: hbs@njau.edu.cn;

and R. R. Walcott; E-mail address: rwalcott@uga.edu

* The $\boldsymbol{e}$-Xtra logo stands for "electronic extra" and indicates that the online version contains one supplementary table.

http://dx.doi.org/10.1094/PHYTO-10-13-0274-R

(C) 2014 The American Phytopathological Society managing both diseases. Both BLB and BLS can occur simultaneously on rice plants and the pathogens can contaminate the resulting rice seedlot. Unfortunately, the pathogens are closely related and difficult to distinguish morphologically and genetically $(10,16)$. In fact, $X$. oryzae pv. oryzae and X. oryzae pv. oryzicola show more than $90 \%$ similarity by DNA:DNA hybridization (30). Additionally, isolation of $X$. oryzae pv. oryzae and $X$. oryzae pv. oryzicola from rice plants and seed by conventional techniques (e.g., selective agar media) is generally difficult, due to the presence of fast-growing, yellow-pigmented bacterial saprophytes (5).

Polymerase chain reaction (PCR) is an in vitro enzymatic method of amplifying specific DNA sequences (17). It is a highly sensitive and specific technique, which has been used successfully to detect pathogens $(11,29,36)$. Recently, PCR-based assays were developed for the detection of $X$. oryzae pv. oryzae and $X$. oryzae pv. oryzicola $(13,27,40)$. Primer set TXT/TXT4R is widely used and targets an insertion sequence (IS1113) of X. oryzae pv. oryzicola. Unfortunately, however, X. oryzae pv. oryzicola DNA yielded false-positive reactions with these primers, because IS1113 is also present in X. oryzae pv. oryzicola (25). To date, the PCR-based methods have not been widely adopted for commercial seed testing for $X$. oryzae pv. oryzae and $X$. oryzae pv. oryzicola because of the low tolerance for the pathogens in seed and the presence of seed compounds that inhibit PCR, leading to false-negative results $(3,13,27)$. To overcome this issue, a combined biological and enzymatic amplification technique (BIOPCR) was developed (25) that substantially improved detection of the pathogen (26). Subsequently, a real-time PCR assay was developed to detect $X$. oryzae pv. oryzae and $X$. oryzae $\mathrm{pv}$. 
oryzicola in rice seed $(14,41)$. However, at present, there are few diagnostic techniques available that can detect $X$. oryzae pv. oryzae and $X$. oryzae pv. oryzicola simultaneously from rice seed. Such a technique would be of great benefit to seed companies and other regulatory agencies because it would reduce the time and seed samples needed to detect both bacteria.

Padlock probes (PLPs) have recently been used to improve detection sensitivity and reduce the cost and time required for plant disease diagnosis (18). PLP-based assays are flexible and easy to adapt to different targets, highly target specific, and suitable for detecting multiple targets (34). PLPs are long oligonucleotides whose ends are complementary to sequences adjacent to the site targeted for PCR amplification. Upon hybridization to the target, the $5^{\prime}$ and $3^{\prime}$ ends of the PLPs are brought into contact, allowing probe circularization by ligation. Ligation and circularization can only take place when both flanks hybridize to their target sequences with high degrees of fidelity. Noncircularized probes are subsequently removed by exonuclease activity. PLPbased assays are highly applicable for detection of plant pathogens and, recently, this technique was combined with dotblot hybridization to facilitate detection of Acidovorax citrulli, the causal agent of bacterial fruit blotch, in cucurbit seed extracts (33). PLPs combined with universal PCR amplification and microarray detection have also facilitated the simultaneous detection of multiple plant pathogens $(31,35)$.

In this study, we designed two PLPs to target genetic loci unique to $X$. oryzae pv. oryzae and $X$. oryzae pv. oryzicola, and evaluated them for pathogen detection in seed. One approach combined the PLPs with dot-blot hybridization for detecting $X$. oryzae pv. oryzae and $X$. oryzae pv. oryzicola individually while the second combined the PLPs with reverse dot-blot hybridization for simultaneous detection of $X$. oryzae pv. oryzae and $X$. oryzae pv. oryzicola in rice seed.

\section{MATERIALS AND METHODS}

Bacterial strains and DNA extraction. In total, 98 bacterial strains, including $33 X$. oryzae pv. oryzae strains, 26 X. oryzae $\mathrm{pv}$. oryzicola strains, and 39 related species, were obtained (Supplementary Table 1). Genomic DNA was extracted from all strains using a TIANamp Bacteria DNA Kit (TIANamp BIOTECH, Beijing, China) according to the manufacturer's directions.

PLP design. The PLPs were designed as described previously (31) to target unique $X$. oryzae pv. oryzae or $X$. oryzae pv. oryzicola $16 \mathrm{~S}-23 \mathrm{~S}$ internal transcribed spacer (ITS) ribosomal DNA (rDNA) sequences. Two 16S-23S ITS sequences from the target pathogens' whole-genome sequences in the National Center for Biotechnology Information (NCBI) GenBank (GenBank accession numbers NC_010717 and NC_017267) were aligned using BioEdit (version 7.0.9.0) (12). The PLPs designed for $X$. oryzae pv. oryzae (P-Xoo) and X. oryzae pv. oryzicola (P-Xoc) were 102 bp long (Table 1) and included regions complementary to the $5^{\prime}$ and $3^{\prime}$ ends flanking sequences of the $X$. oryzae pv. oryzae or $X$. oryzae pv. oryzicola target regions, respectively. The $5^{\prime}$ arm of the PLP was longer than its $3^{\prime}$ arm; the $5^{\prime}$ arm sequence (T1) was 28 nucleotides (nt) long and the $3^{\prime}$ arm sequence (T2) was $14 \mathrm{nt}$. The universal primer sites and a unique sequence identifier, called Zipcode, were between these segments. The Zipcode sequences were selected from NCBI (GenBank DQ.668361), containing more than five mismatches to known sequences in the public domain (31).

Ligation and exonuclease treatment. $X$. oryzae pv. oryzae and $X$. oryzae pv. oryzicola genomic DNA digested separately with EcoRI, HindIII, and BamHI (TaKaRa, Dalian, China) for $30 \mathrm{~min}$, and was used as a template as described below. Cycled ligation was conducted in $10-\mu$ l reactions containing $20 \mathrm{mM}$ Tris- $\mathrm{HCl}(\mathrm{pH}$ 9.0), $25 \mathrm{mM} \mathrm{KCH} 3 \mathrm{COO}, 10 \mathrm{mM} \mathrm{Mg}\left(\mathrm{CH}_{3} \mathrm{COO}\right)_{2}$, $10 \mathrm{mM}$ dithiothreitol, $1 \mathrm{mM}$ nicotinamide adenine dinucleotide, $0.1 \%$ Triton $\mathrm{X}$ 100, $2.4 \mathrm{U}$ of Taq DNA ligase (New England Biolabs, Beijing, China), and $50 \mathrm{pM}$ each PLP (P-Xoo or P-Xoc for X. oryzae pv. oryzae and $X$. oryzae pv. oryzicola DNA, respectively). For simultaneous detection of both pathogens, $10-\mu$ l reactions containing both PLPs were used, and the concentration of each PLP was $50 \mathrm{pM}$. Reaction mixtures were kept on ice and transferred rapidly into a thermal cycler. After $5 \mathrm{~min}$ at $95^{\circ} \mathrm{C}, 20$ cycles of $30 \mathrm{~s}$ at $95^{\circ} \mathrm{C}$ and $5 \mathrm{~min}$ at $65^{\circ} \mathrm{C}$ were conducted, followed by $15 \mathrm{~min}$ at $95^{\circ} \mathrm{C}$ to inactivate the reaction. After ligation, $10 \mu \mathrm{l}$ of exonuclease mixture $(10 \mathrm{mM}$ Tris- $\mathrm{HCl}$ [pH 9.0], $4.4 \mathrm{mM} \mathrm{MgCl}$, bovine serum albumin at $0.1 \mathrm{mg} / \mathrm{ml}, 0.5 \mathrm{U}$ of Exonuclease I [TaKaRa], and $0.5 \mathrm{U}$ of Exonuclease III [TaKaRa]) were added to each reaction, and the samples were incubated at $37^{\circ} \mathrm{C}$ for $15 \mathrm{~min}$, followed by inactivation at $95^{\circ} \mathrm{C}$ for $3 \mathrm{~min}$.

To determine the specificity of the PLP assay, genomic DNA from 98 bacterial strains was resuspended in a $100-\mu$ Tris-EDTA (TE) buffer and subjected to cycled ligation followed by PCR amplification with each PLP individually, as described above.

To determine the amplification efficiency of the PLP assay, 10fold serial dilutions of pure $X$. oryzae pv. oryzae and $X$. oryzae $\mathrm{pv}$. oryzicola genomic DNA were generated, ranging from $10 \mathrm{ng} / \mu \mathrm{l}$ to $100 \mathrm{fg} / \mu \mathrm{l}$, and tested by the PLP assay as described above. For comparison, conventional PCR was conducted using primers OSF1/OSR1 (40) and XoocF/XoocR (40) for X. oryzae pv. oryzae and $X$. oryzae pv. oryzicola, respectively. This experiment was repeated five times.

PCR amplification. Amplification of PLPs was carried out in an ABI 2720 thermal cycler (Applied Biosystems, CA) in 25- $\mu \mathrm{l}$ reactions containing $3 \mathrm{mM} \mathrm{MgCl} 2,200 \mathrm{nM}$ dNTP, $300 \mathrm{nM}$ primers P1-F (5'-CCGAGATGTACCGCTATCGT-3') and P2-R (5'-TCATGCTGCTAACGGTCGAG-3'), 1 U of Taq HotStart polymerase (TaKaRa), 0.6 U of uracil DNA glycosylase (New England Biolabs), and $3 \mu \mathrm{l}$ of ligation-exo mixture as template. For simultaneous detection of $X$. oryzae pv. oryzae and X. oryzae pv. oryzicola DNA, primer P1-F was labeled with digoxigenin (DIG). The reaction mixture was initially incubated at $50^{\circ} \mathrm{C}$ for $2 \mathrm{~min}$, followed by $10 \mathrm{~min}$ of denaturation at $95^{\circ} \mathrm{C}$ and 40 cycles of $15 \mathrm{~s}$ at $95^{\circ} \mathrm{C}$ and $1 \mathrm{~min}$ at $60^{\circ} \mathrm{C}$. The reaction was then immediately cooled to $10^{\circ} \mathrm{C}$.

TABLE 1. Padlock probes and cZipcode probe used

\begin{tabular}{ll}
\hline Probes $^{\mathrm{a}}$ & \multicolumn{1}{c}{ Sequence } \\
\hline PLP-Xoo $^{\text {CACGGCATATAGCTCCGAGGCAACTTGGCTCGACCGTTAGCAGCATGACCGAGATGTACCGCTATCGTGAATCGCCTACAAT }}$ \\
& $\begin{array}{l}\text { TCTGTCTGTACTCCACACAG } \\
\text { PLP-Xoc }\end{array}$ \\
& $\begin{array}{c}\text { GCTCCAAGGCAACTTGGGGTTATATGGTCTCGACCGTTAGCAGCATGACCGAGATGTACCGCTATCGTGCGGCATACGTTCGT } \\
\text { CAAATCAACACGGCATATC }\end{array}$ \\
cZip-Xoo & CTTAGCGGATGTTAAGACAG \\
cZip-Xoc & CGCCGTATGCAAGCAGTTA \\
cZip-C1 & TAGCCGGACATTAGCCTAGC \\
cZip-C2 & GGCTGAGATCCTAGCACCTA \\
\hline
\end{tabular}

a The $5^{\prime}$ and $3^{\prime}$ ends of the primers that are complementary to the target sequences are indicated by dotted lines. Regions where the two padlock probe-specific primers (P1 and P2) (31) bind for polymerase chain reaction amplification are underlined. The Zipcode sequences, with the unique sequence, specific to the pathogen or target to be detected are in bold. cZipcode probe was the complementary to the Zipcode sequence. 
Dot-blot hybridization. Dot-blot hybridization was conducted as described previously (24,33). Briefly, $1 \mu \mathrm{l}$ of PLP amplicons was spotted onto a specific position on a nylon membrane (Hybond-N ${ }^{+}$; Amersham, Arlington Heights, USA). Ultraviolet cross-linking of DNA to the membrane was carried out for $30 \mathrm{~s}$ on a UV hybrilinker (UVP HL-2000); then, the membrane was rinsed briefly in $2 \times \mathrm{SSC}(1 \times \mathrm{SSC}$ is $0.15 \mathrm{M} \mathrm{NaCl}$ plus $0.015 \mathrm{M}$ sodium citrate) containing $1 \%$ sodium dodecyl sulfate (SDS) for $2 \mathrm{~min}$ at room temperature. The membrane was subsequently air dried for approximately $10 \mathrm{~min}$ at room temperature. Then, $1 \mu \mathrm{l}$ of 3 pM cZipcode oligonucleotides was labeled with DIG using a DIG DNA labeling kit (Roche Applied Science, Mannheim, Germany), according to the manufacturer's instruction. Hybridization was then carried out for $4 \mathrm{~h}$ at $42^{\circ} \mathrm{C}$. Membranes were washed twice in $2 \times \mathrm{SSC}$ and $0.1 \% \times \mathrm{SDS}$ for $5 \mathrm{~min}$ at room temperature, twice in $0.5 \% \times \mathrm{SSC}$ and $0.1 \% \times \mathrm{SDS}$ for $15 \mathrm{~min}$ at $68^{\circ} \mathrm{C}$, and once in maleic acid buffer for $2 \mathrm{~min}$ at room temperature. To detect hybridization, the membrane was incubated with anti-DIG antibody conjugated with alkaline phosphatase diluted $1: 250$ in $0.1 \mathrm{M}$ Tris- $\mathrm{HCl}$ and $0.15 \mathrm{M} \mathrm{NaCl}$ with $1 \%$ blocking reagent (Roche Applied Science). After washing the membrane three times in detection buffer $(0.1 \mathrm{M}$ Tris- $\mathrm{HCl}$ and $0.1 \mathrm{M} \mathrm{NaCl}$, $\mathrm{pH}$ 9.5), a substrate consisting of nitroblue tetrazolium-bromochloro-indolyl phosphate (Roche Applied Science) was layered the membrane for 2 to $8 \mathrm{~h}$ in the dark. The chromogenic reaction was then stopped by dipping membranes in TE buffer $(1 \mathrm{mM}$ EDTA and $1 \mathrm{mM}$ TrisCl, pH 8.0) for approximately $5 \mathrm{~min}$.

Reverse dot-blot hybridization. For simultaneous detection of $X$. oryzae pv. oryzae and $X$. oryzae pv. oryzicola, $1 \mu \mathrm{l}$ of $1 \mathrm{mM}$ cZipcode oligonucleotides was spotted on the nylon membrane (Hybond- $\mathrm{N}^{+}$; Amersham) three times. Ultraviolet cross-linking of DNA to the membrane was carried out for $30 \mathrm{~s}$ on a UV hybrilinker (UVP HL-2000); then, the membrane was rinsed briefly in $2 \times$ SSC containing $1 \%$ SDS for 2 min at room temperature. The membrane was subsequently air dried for approximately $10 \mathrm{~min}$ at room temperature. Then, 5- $\mu$ l DIG-labeled PLP amplicons were added to $5 \mathrm{ml}$ of hybridization solution (Roche Applied Science) and hybridization was carried out for $4 \mathrm{~h}$ at $42^{\circ} \mathrm{C}$. The membranes were washed and processed for color detection as described as above.

Detection of $X$. oryzae pv. oryzae and $X$. oryzae pv. oryzicola in rice seed. Artificially infested rice seed samples were processed for pathogen extraction as described by Gnanamanickam et al. (9). Briefly, rice seed ( $5 \mathrm{~g}$ ) were artificially inoculated by incubation for $1 \mathrm{~h}$ in a 200-ml cell suspension containing X. oryzae pv. oryzae PXO99 or X. oryzae pv. oryzicola RS105 at approximately $1 \times 10^{8} \mathrm{CFU} / \mathrm{ml}$ of $0.01 \mathrm{M}$ phosphate-buffered saline (PBS). Control seed samples were treated in a similar way with sterile PBS. Infested seed were then incubated at $4^{\circ} \mathrm{C}$ for $2 \mathrm{~h}$ to permit adsorption of bacteria or buffer onto the seed. Seed was air dried and then mixed with noninfested seed to generate seedlots with $0 \% \quad(0 / 1,000$ seed), $0.2 \%$ (2/1,000 seed) $2 \%$ (20/1,000 seed), 5\% (50/1,000 seed), and 10\% (100/1,000 seed) infestation. Seedlots were incubated with $200 \mathrm{ml}$ of PBS for $4 \mathrm{~h}$ on an incubator shaker (Zhicheng, Shanghai, China). Seed samples ( $n=1,000 \mathrm{seed} / \mathrm{lot})$ were incubated in $50 \mathrm{ml}$ of PBS plus $0.2 \%$ Tween 20 for $2 \mathrm{~h}$ on a shaker (Zhicheng). The seed extract was decanted and centrifuged at $12,000 \times g$ for $10 \mathrm{~min}$. The supernatant was removed, the pellet was suspended in $1 \mathrm{ml}$ of PBS, and $2 \mu \mathrm{l}$ of seed extract was used as template for the PLP assay combined with dot-blot hybridization as described above. For comparison, conventional PCR was conducted directly on $2 \mu \mathrm{l}$ of seed extract of the pellet using primers OSF1/OSR1 (40) and XoocF/XoocR (40) for X. oryzae pv. oryzae and X. oryzae pv. oryzicola, respectively. This experiment was repeated five times.

Detection of $X$. oryzae pv. oryzae and $X$. oryzae pv. oryzicola in naturally infested rice seed samples. To evaluate the ability of the PLP assay to detect $X$. oryzae pv. oryzae and $X$. oryzae pv. oryzicola in naturally infested seed, samples collected from Jiangsu (sample numbers 09Zao-1 to 09Zao-33) and Hainan provinces (sample numbers S1 to S14) were tested as described above. Seedlots that were positive for both pathogens by simplex PLP-based assay were tested again for by duplex PLP combined with reverse dot-bot hybridization. For comparison, samples from the same lots were tested by conventional PCR using primers OSF1/OSR1 (40) and XoocF/XoocR (40). Seed samples $(n=$ 1,000 seed) from each lot and the negative control from healthy seed wash were processed as described above, and this experiment was repeated five times. To confirm the results, $100 \mu \mathrm{l}$ of seed wash from positive seedlots was plated on XOS semiselective media (5). After incubation for $24 \mathrm{~h}$ at $28^{\circ} \mathrm{C}$, putative $X$. oryzae colonies were selected for verification by PCR with OSF1/OSR 1 and XoocF/XoocR primer sets. To further confirm the identity of the putative $X$. oryzae strains, partial 16S rDNA sequences were generated (TaKaRa) using universal 16S rDNA primers $f d 2 / r p 1$ (37). These sequence data were used to query the NCBI GenBank database with the BLASTn algorithm (1).

\section{RESULTS}

Specificity of PLPs. PLPs in combination with dot-blot hybridization or reverse dot-blot hybridization were applied to differentiate $X$. oryzae pv. oryzae and $X$. oryzae pv. oryzicola. Hybridization signals generated from the probes $\mathrm{P}-\mathrm{Xoo}$ and $\mathrm{P}$-Xoc indicated that they were specific to their respective target sequences and facilitated differentiation of $X$. oryzae pv. oryzae and $X$. oryzae pv. oryzicola. None of the $26 X$. oryzae pv. oryzicola strains produced a hybridization signal with P-Xoo. Likewise, none of the $33 X$. oryzae pv. oryzae strains produced a hybridization signal with the P-Xoc assay. As expected, the PLPs did not yield hybridization signals with DNA from 39 related bacterial species.

Sensitivity of PLP-based assays. To determine the sensitivity of the PLP assays, tests were performed using serial 10-fold dilutions (from $10 \mathrm{ng}$ to $100 \mathrm{fg}$ ) of pure $X$. oryzae pv. oryzae PXO99 and X. oryzae pv. oryzicola RS105 DNA using the corresponding PLPs in simplex reactions. PCR facilitated the detection of $1 \mathrm{pg}$ of $X$. oryzae pv. oryzae and X. oryzae pv. oryzicola genomic DNA (Fig. 1).

Simultaneous detection of $X$. oryzae pv. oryzae and $X$. oryzae pv. oryzicola by PLPs. For simultaneous detection of $X$. oryzae pv. oryzae and $X$. oryzae pv. oryzicola, a mixture of the two PLPs was ligated with various template genomic DNAs of $X$. oryzae pv. oryzae PXO99 and X. oryzae pv. oryzicola RS105 (1 pg and $500 \mathrm{pg}$ ), treated with exonucleases, and subjected to PCR using DIG-labeled forward primers. The labeled PLP amplicons were analyzed on nylon membranes that allowed the simultaneous detection of $X$. oryzae pv. oryzae and $X$. oryzae pv. oryzicola DNA on a single membrane. The ability of the PLP-based assay to detect two pathogens simultaneously was evaluated. Mixtures of equal concentrations of $X$. oryzae pv. oryzae and $X$. oryzae pv. oryzicola genomic DNAs were tested. The pathogens were correctly and unambiguously identified by both PLPs in $100 \%$ of the experiments (Table 2). To evaluate the robustness of the detection assay, we tested the detection threshold for $X$. oryzae pv. oryzae PXO99 and X. oryzae pv. oryzicola RS105 DNA in the presence of high concentrations of nontarget DNA. As little as $1 \mathrm{pg}$ of PXO99 DNA was detected in $100 \%$ of the attempts in the presence of $500 \mathrm{pg}$ of RS105 DNA (Fig. 2A and B). Conversely, the detection threshold was $1 \mathrm{pg}$ for RS105 (100\% of attempts) in the presence of $500 \mathrm{pg}$ of PXO99 DNA (Fig. 2E and F).

Detection of $X$. oryzae pv. oryzae and $X$. oryzae pv. oryzicola in artificially infested rice seed. Conventional PCR detected $X$. oryzae pv. oryzae and X. oryzae pv. oryzicola in 40 and $20 \%$, respectively, of rice seedlots with $10 \%$ artificially infested seed of each pathogen. Conventional PCR failed to detect either pathogen 
in seedlots with lower levels of infestation. In contrast, the P-Xoo-based assay detected X. oryzae pv. oryzae in $100 \%$ of the seedlots with 10, 5, and 2\% infestation (Fig. 3A; Table 2). Similarly, the P-Xoc-based assay detected $X$. oryzae pv. oryzicola in $100 \%$ of rice seedlots with $10,5,2$, and $0.2 \%$ infestation (Fig. 3B; Table 2). Using naturally infested seedlots, the P-Xoo-based assay facilitated the detection of $X$. oryzae pv. oryzae in $39.3 \%$ (13 of 33) of commercial rice seedlots from Jiangsu (Fig. 4) and the P-Xoc-based assay detected X. oryzae pv. oryzicola in $21.3 \%$ (10 of 47) of commercial rice seedlots from Jiangsu and Hainan (Fig. 5). To confirm the results, seed wash from the seedlots that were positive based on the PLP-based assays were plated on XOS semiselective media. All seed wash yielded corresponding colonies. In contrast, conventional PCR using OSF1/OSR1 primers detected $X$. oryzae pv. oryzae in 3 of 33 rice seedlots, and the XoocF/XoocR primers detected X. oryzae pv. oryzicola in 4 of 47 rice seedlots.

Simultaneous detection of $X$. oryzae pv. oryzae and $X$. oryzae pv. oryzicola in naturally infested rice seed. According to the above results, the PLP-based assay facilitated the detection of both $X$. oryzae pv. oryzae and X. oryzae pv. oryzicola singly from two seedlots, 09Zao-11 and 09Zao-15 (Figs. 4 and 5). To evaluate the ability of the PLP-based assay to simultaneously detect $X$. oryzae pv. oryzae and $X$. oryzae pv. oryzicola, samples from 09Zao-11 and 09Zao-15 seedlots were tested using both PLPs with reverse dot-blot hybridization as described above. Using the PLP assays together, $X$. oryzae pv. oryzae and $X$. oryzae pv. oryzicola were detected simultaneously from both seed samples (Fig. 6).

\section{DISCUSSION}

To the best of our knowledge, this is the first report on the application of the PLP-based assay for the simultaneous detection of $X$. oryzae pv. oryzae and $X$. oryzae pv. oryzicola in rice seed. Our data provide proof of this concept and indicate that, after further optimization, there is great potential for this technique to be employed for other pathogens in a wide range of seed. Interestingly, the PLP-based assay detected $X$. oryzae pv. oryzae and $X$. oryzae pv. oryzicola in a greater percentage of naturally infected rice seedlots than conventional PCR. The PLP-based assay detected $X$. oryzae pv. oryzae in $21.2 \%$ of the rice seedlots from Jiangsu, compared with $6.4 \%$ by conventional PCR. In a similar manner, the PLP-based assay detected $X$. oryzae pv. oryzicola in $39.4 \%$ of rice seedlots from Hainan, compared with $18.2 \%$ for conventional PCR. All seedlots that were determined to

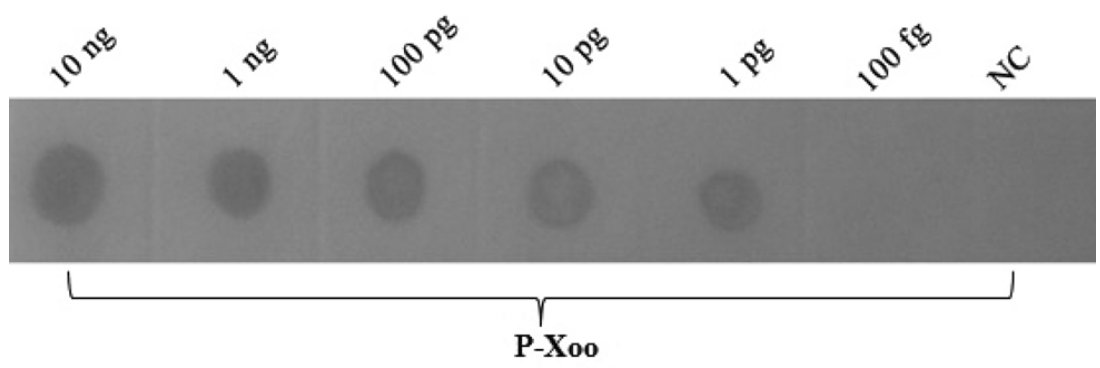

A

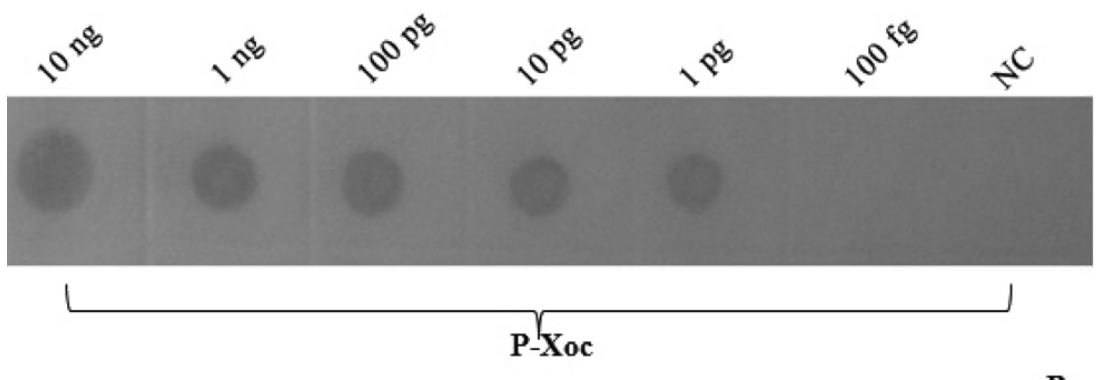

B

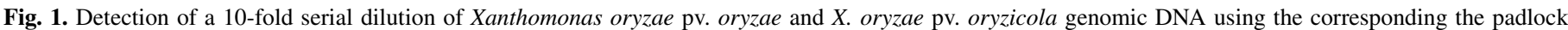
probes (PLPs). Template DNAs are indicated on the top, while the PLPs are shown on the bottom. $\mathrm{NC}=$ negative control, double-distilled $\mathrm{H}_{2} \mathrm{O}$.

TABLE 2. Sensitivity of the padlock probes P-Xoo and P-Xoc

\begin{tabular}{|c|c|c|c|c|c|c|c|c|c|}
\hline \multicolumn{2}{|c|}{ Amount (pg) ${ }^{\mathrm{a}}$} & \multicolumn{2}{|c|}{ Frequency $^{\mathrm{b}}$} & \multirow{2}{*}{$\frac{X o o \text { infestation }^{c}}{(\%)}$} & \multicolumn{2}{|c|}{ Frequency $^{\mathrm{b}}$} & \multirow{2}{*}{$\frac{X o c \text { infestation }^{\mathrm{d}}}{(\%)}$} & \multicolumn{2}{|c|}{ Frequency $^{\mathrm{b}}$} \\
\hline Хоо & Хос & P-Xoo & P-Xoc & & PLP assay & Direct PCR & & PLP assay & Direct PCR \\
\hline 500 & 500 & $(5 / 5) 100$ & $(5 / 5) 100$ & 10 & $(5 / 5) 100$ & $(2 / 5) 100$ & 10 & $(5 / 5) 100$ & $(1 / 5) 100$ \\
\hline 500 & 1 & $(5 / 5) 100$ & $(5 / 5) 100$ & 5 & $(5 / 5) 100$ & 0 & 5 & $(5 / 5) 100$ & 0 \\
\hline 1 & 500 & $(5 / 5) 100$ & $(5 / 5) 100$ & 2 & $(5 / 5) 100$ & 0 & 2 & $(5 / 5) 100$ & 0 \\
\hline 1 & 1 & $(5 / 5) 100$ & $(5 / 5) 100$ & 0.2 & 0 & 0 & 0.2 & $(5 / 5) 100$ & 0 \\
\hline 1 & 0 & $(5 / 5) 100$ & 0 & 0.1 & 0 & 0 & 0.1 & 0 & 0 \\
\hline 0 & 1 & 0 & $(5 / 5) 100$ & 0 & 0 & 0 & 0 & 0 & 0 \\
\hline 0 & 0 & 0 & 0 & $\ldots$ & $\ldots$ & $\ldots$ & $\ldots$ & $\ldots$ & $\cdots$ \\
\hline
\end{tabular}

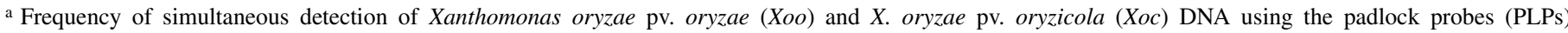
combined with reverse dot-blot hybridization. Template amount (pg).

$\mathrm{b}$ Detection frequency $=$ the number of positive assays divided by the number of samples tested.

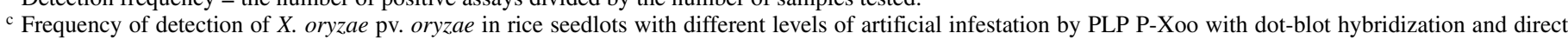
polymerase chain reaction (PCR) using primers OSF1/OSR1.

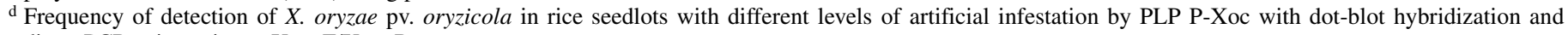
direct PCR using primers XoocF/XoocR. 


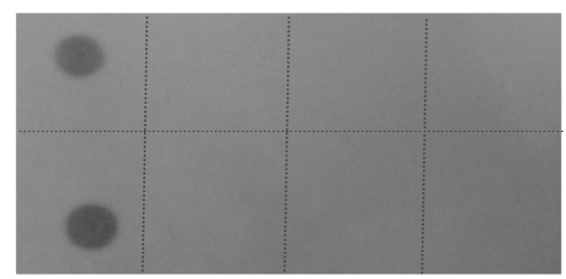

A

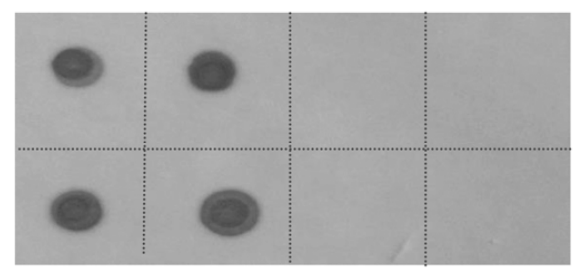

C

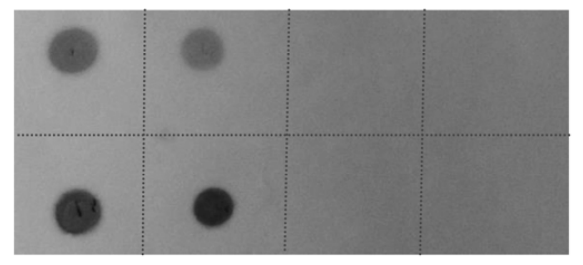

$\mathbf{E}$

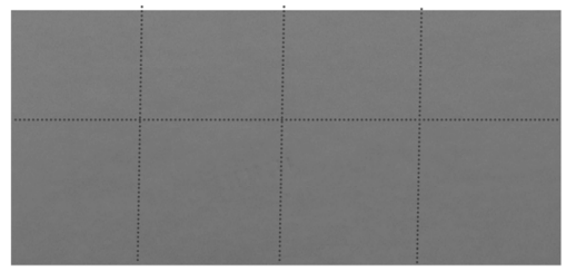

G

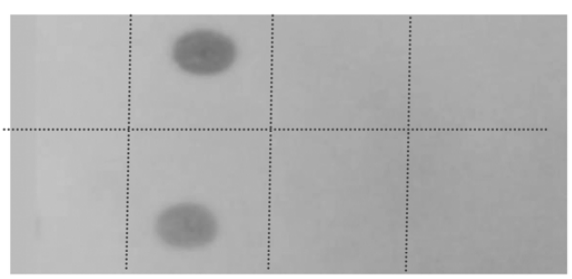

B

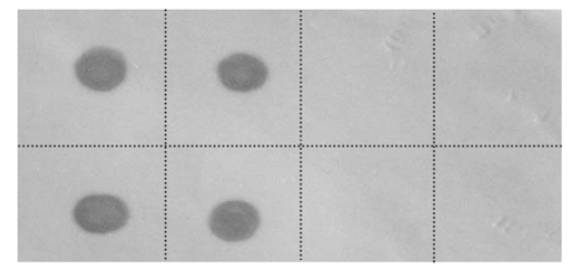

D

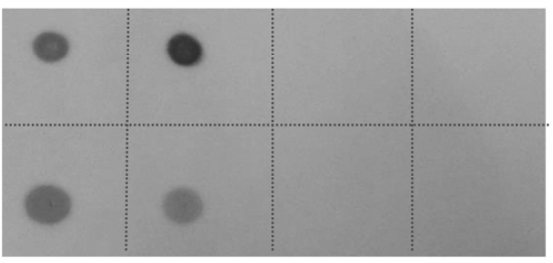

F

\begin{tabular}{|l|l|l|l|}
\hline cZip-Xoo & cZip-Xoo & cZip-cl & cZip-cl \\
\hline cZip-Xoos & cZip-Xoos & cZip-c2 & cZip-c2 \\
\hline
\end{tabular}

$\mathbf{H}$

Fig. 2. Detection of genomic DNAs corresponding to complex pathogen DNAs on the nylon membrane using the padlock probes P-Xoo and P-Xoc combined with dot-blot hybridization. Analyzed targets were as follows: A, X. oryzae pv. oryzae PXO99, $1 \mathrm{pg}$ and X. oryzae pv. oryzicola RS105, 0 pg; B, PXO99, 0 pg and RS105, 1 pg; C, PXO99, 500 pg and RS105, 500 pg; D, PXO99, 1 pg and RS105, 1 pg; E, PXO99, 1 pg and RS105, 500 pg; F, PXO99, 500 pg and RS105, 1 pg; $\mathrm{G}$, double-distilled $\mathrm{H}_{2} \mathrm{O} ; \mathrm{H}$, Layout of targets from each cZipcode oligonucleotides on the membrane.
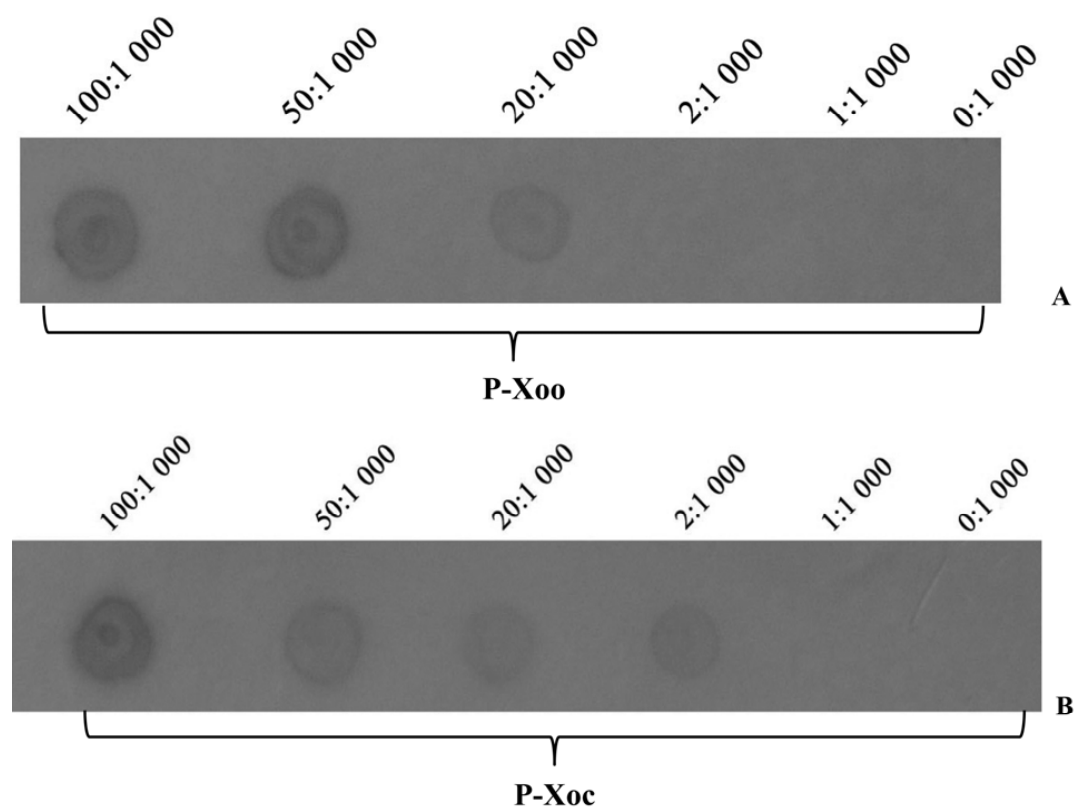

Fig. 3. Detection of A, Xanthomonas oryzae pv. oryzae and $\mathbf{B}, X$. oryzae pv. oryzicola in rice seedlots with different levels of artificial infestation ranging from 10 to $0 \%$ using the corresponding padlock probe (PLP) assay combined with dot-blot hybridization. PLPs are shown on the bottom. 
be positive by the PLP-based assay were confirmed by isolation of the respective pathogens on semiselective media and subsequent assays.

Microarray- or macroarray-based multiplex assays that use universal primers to detect variable regions of PLPs have been used to facilitate high-throughput diagnostics $(8,35)$. In fact, because of their high sensitivity and specificity, PLPs have been used to detect single-nucleotide variations in DNA sequences $(2,6)$. When used as a seed health assay, the PLP approach offers numerous advantages over other techniques such as multiplex PCR, which is commonly used for amplifying multiple targets in a single PCR assay $(7,32)$. For example, multiplex PCR is negatively affected by its complexity, low amplification efficiency, and variable efficiency, with different ratios of template concentrations (39). In this study, a mixture of two PLPs was ligated on various template DNAs. After selecting the target complementary regions, the ligated PLPs were amplified by PCR, which used a pair of universal primers to avoid interference and competition among reactions. The labeled PLP amplicons were analyzed by complementary Zipcode (cZipcode) macroarrays, which enabled the duplex detection of two pathogens on a single nylon. In this study, PLPs resulted in an increase in X. oryzae pv. oryzae and $X$. oryzae pv. oryzicola detection sensitivity over direct PCR. With respect to effectiveness, the PLP-based assay simultaneously also detected $X$. oryzae pv. oryzae and $X$. oryzae pv. oryzicola in rice seed extracts without cross reaction.

A second advantage of the PLP-based approach is the fact that the nylon membrane used is much cheaper than a standard microarray chip. The tag array used in our study contained four cZipcode probes in two replicates with two control probes. Unique Zipcode sequences were selected for each probe. This layout allows for future expansion of the PLP set to target other

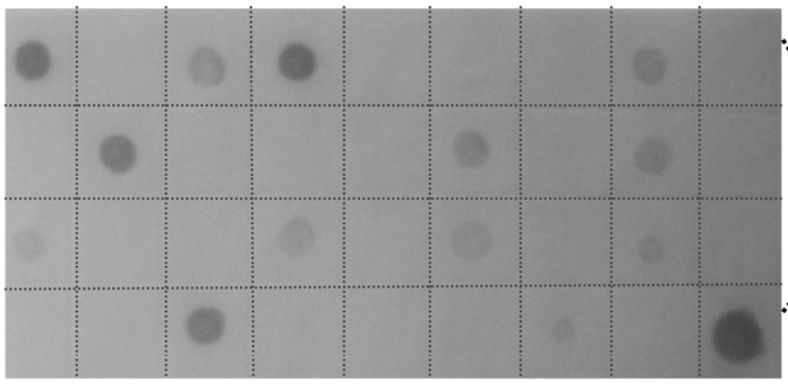

A

\begin{tabular}{|c|c|c|c|c|c|c|c|c|}
\hline 1 & 2 & 3 & 4 & 5 & 6 & 7 & 8 & 9 \\
\hline 10 & 11 & 12 & 13 & 14 & 15 & 16 & 17 & 18 \\
\hline 19 & 20 & 21 & 22 & 23 & 24 & 25 & 26 & 27 \\
\hline 28 & 29 & 30 & 31 & 32 & 33 & 34 & 35 & 36 \\
\hline
\end{tabular}

B

Fig. 4. Detection of Xanthomonas oryzae pv. oryzae in rice seed samples using padlock probe P-Xoo combined with dot-blot hybridization. A, Layout of targets from each sample on membrane. B, Analyzed samples = 1 to 33, seedlots 09Zao-1 to 09Zao-33; 34 = negative control, the $X$. oryzae-free seed wash; $35=$ negative control, double-distilled $\mathrm{H}_{2} \mathrm{O}$; and 36 = positive control, PXO99.

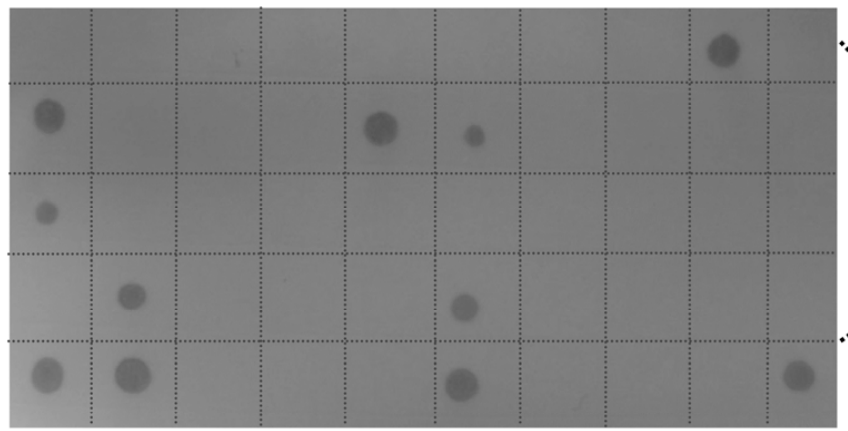

A

\begin{tabular}{|c|c|c|c|c|c|c|c|c|c|}
\hline 1 & 2 & 3 & 4 & 5 & 6 & 7 & 8 & 9 & 10 \\
\hline 11 & 12 & 13 & 14 & 15 & 16 & 17 & 18 & 19 & 20 \\
\hline 21 & 22 & 23 & 24 & 25 & 26 & 27 & 28 & 29 & 30 \\
\hline 31 & 32 & 33 & 34 & 35 & 36 & 37 & 38 & 39 & 40 \\
\hline 41 & 42 & 43 & 44 & 45 & 46 & 47 & 48 & 49 & 50 \\
\hline
\end{tabular}

B

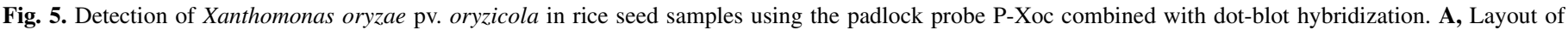

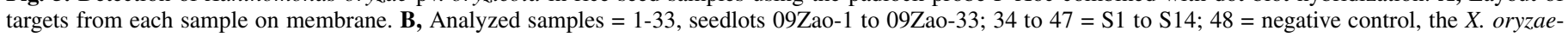
free seed wash; 49 = negative control, double-distilled $\mathrm{H}_{2} \mathrm{O}$; and 50 = positive control, RS105.

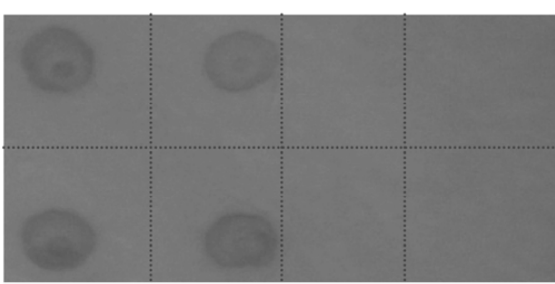

A

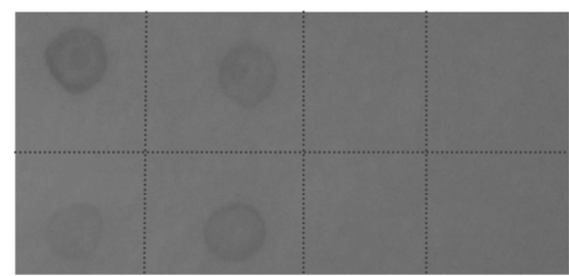

B

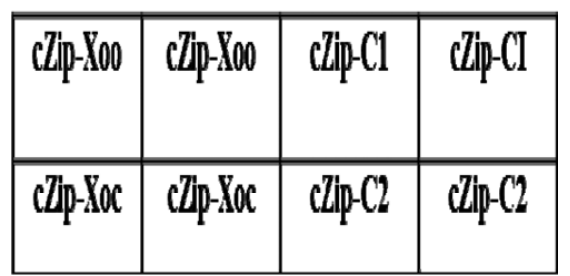

C

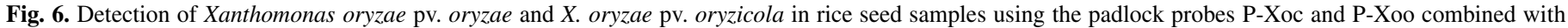

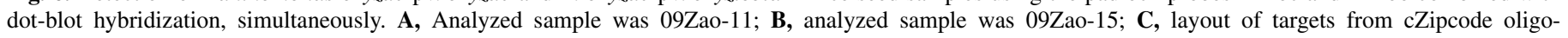
nucleotides on membrane. 
pathogens and thereby enable higher throughput screening. Hence, this approach could be used to test rice seed for a wider array of pathogens, making it a universal rice seed health assay. The only limitations would be the ability to extract adequate quantities of pathogen nucleic acids from seed tissues. Nevertheless, we believe this approach could be applied all seedborne rice pathogens.

A third advantage of the PLP-based assay is its efficiency with regards to the time to assay completion. Including sample processing, the PLP assay required 13 to $19 \mathrm{~h}$ to test $\approx 100$ rice seed samples ( $n=1,000 \mathrm{seed} / \mathrm{sample}$ ). This was substantially less time than the 10 to 14 days required for traditional culturing and subsequent bacterial identification. Although direct PCR could be completed in 3 to $4 \mathrm{~h}$, the PLP-based technique detected a higher percentage of positive seed samples.

Our results proved the concept that PLP-based assays can be used for the simultaneous detection of multiple pathogens in seed. As such, this approach not only could be used for the detection of $X$. oryzae pv. oryzae and $X$. oryzae pv. oryzicola in rice seed but also could serve as a universal assay for all seedborne rice pathogens. As such, this could be an important tool for limiting the dissemination of plant pathogens on rice and other seed.

\section{ACKNOWLEDGMENTS}

This research was supported by the China Research Special Fund for Public Welfare Industry (number 201303015) and The National '863' Program (2012AA101501)

\section{LITERATURE CITED}

1. Altschul, S. F., Madden, T. L., Schaffer, A. A., Zhang, J., Zhang, Z., Miller, W., and Lipman, D. J. 1997. Gapped BLAST and PSI-BLAST: A new generation of protein database search programs. Nucleic Acids Res. 25:3389-3402.

2. Antson, D. O., Mendel-Hartvig, M., Landegren, U., and Nilsson, M. 2003. PCR generated padlock probes distinguish homologous chromosomes through quantitative fluorescence analysis. Eur. J. Hum. Genet. 11:357-363.

3. Boer, S. H., Ward, L. J., Li, X., and Chittaranjan, S. 1995. Attenuation of PCR inhibition in the presence of plant compounds by addition of blotto. Nucleic Acids Res. 23:2567-2568.

4. Buddenhagen, I. W. 1985. Rice disease evaluation in Madagascar. Int. Rice Commun. Newsl. 34:74-78.

5. Di, M., Ye, H., Schaad, N. W., and Roth, D. A. 1991. Selective recovery of Xanthomonas spp. from rice seed. Phytopathology 81:1358-1363.

6. Edwards, K. J., Reid, A. L., Coghill, J. A., Berry, S. T., and Barker, G.L. 2009. Multiplex single nucleotide polymorphism (SNP)-based genotyping in allohexaploid wheat using padlock probes. Plant Biotechnol. J. 7:375390.

7. Elnifro, E. M., Ashshi, A. M., Cooper, R. J., and Klapper, P. E.. 2000. Multiplex PCR: Optimization and application in diagnostic virology. Clin. Microbiol. Rev. 13:559-570.

8. Fessehaie, A., Solke, H., Boer, D., and Levesque, A. C. 2003. An oligonucleotide array for the identification and differentiation of bacteria pathogenic on potato. Phytopathology 93:262-269.

9. Gnanamanickam, S. S., Shigaki, T., Medalla, E. S., Mew, T. W., and Alvarez, A. M. 1994. Problems in detection of Xanthomonas oryzae pv. oryzae in rice seed and potential for improvement using monoclonal antibodies. Plant Dis. 78:173-178.

10. Goto, M. 1992. Fundamentals of Bacterial Plant Pathology. Academic Press, San Diego, CA.

11. Ha, Y., Fessehaie, A., Ling, K. S., Wechter, W. P., Keinath, A. P., and Walcott, R. R. 2009. Simultaneous detection of Acidovorax avenae subsp. citrulli and Didymella bryoniae in cucurbit seedlots using magnetic capture hybridization and real-time polymerase chain reaction. Phytopathology 99:666-678.

12. Hall, T. 1994. BioEdit: A user-friendly biological sequence alignment editor and analysis program for Windows 95/98/NT. Nucleic Acids Symp. Ser. 41:95-98.

13. Kang, M. J., Shim, J. K., Cho, M. S., Seol, Y. J., Hahn, J. H., Hwang, D. J., and Park, D. S. 2008. Specific detection of Xanthomonas oryzae pv. oryzicola in infected rice plant by use of PCR assay targeting a membrane fusion protein gene. J. Microbiol. Biotechnol. 18:1492-1495.

14. Liao, X., Zhu, S., Zhao, W., Luo, K., and Qi, Y. 2003. Detection and identification of Xanthomonas oryzae pv. oryzae and Xanthomonas oryzae pv. oryzicola by real-time fluorescent PCR. Acta Microbiol. Sin. 43:626-634.

15. Mew, T. W. 1992. Bacterial leaf streak. Page 11 in: Compendium of Rice Diseases. R. K. Webster and P. S. Gunnell, eds. American Phytopathological Society, St. Paul, MN.

16. Mew, T. W., Alvarez, A. M., Leach, J. E., and Swings, J. 1993. Focus on bacterial blight of rice. Plant Dis. 77:5-12.

17. Mullis, K., Faloona, F., Scharf, S., Saiki, R., Horn, G., and Erlich, H. 1986. Specific enzymatic amplification of DNA in vitro: The polymerase chain reaction. Cold Spring Harb. Symp. Quant. Biol. 51:263-273.

18. Nilsson, M., Malmgren, H., Samiotaki, M., Kwiatkowski, M., Chowdhary, B. P., and Landegren, U. 1994. Padlock probes: Circularizing oligonucleotides for localized DNA detection. Science 265:2085-2088.

19. Niño-Liu, D. O., Ronald, P. C., and Bogdanove, A. J. 2006. Xanthomonas oryzae pathovars: Model pathogens of a model crop. Mol. Plant Pathol. 7:303-324.

20. Opina, O. S., and Exconde, O. R. 1971. Assessment of yield loss due to bacterial leaf streak of rice. Philipp. Phytopathol. 7:35-39.

21. Ou, S. H. 1985. Rice Diseases. Commonwealth Agricultural Bureau, Kew, Surrey, UK.

22. Reddy, A. P. K., Mackenzie, D. R., Rouse, D. I., and Rao, A. V. 1979. Relationship of bacterial leaf blight Xanthomonas oryzae severity to grain yield of rice Oryza sativa. Phytopathology 69:967-969.

23. Ryba-White, M., Notteghem, J. L., and Leach, J. E. 1995. Comparison of Xanthomonas oryzae pv. oryzae strains from Africa, North America, and Asia by restriction fragment length polymorphism analysis. Int. Rice Res. Notes 20:25-26.

24. Saiki, R. K., Walsh, P. S., Levenson, C. H., and Erlich, H. A. 1989. Genetic analysis of amplified DNA with immobilized sequence-specific oligonucleotide probes. Proc. Natl. Acad. Sci. USA 86:6230-6234.

25. Sakthivel, N., Mortensen, C. N., and Mathur, S. B. 2001. Detection of Xanthomonas oryzae pv. oryzae in artificially inoculated and naturally infected rice seeds and plants by molecular techniques. Appl. Microbiol. Biotechnol. 56:435-441.

26. Schaad, N. W., Cheong, S. S., Tamaki, S., Hatziloukas, E., and Panopoulos, N. J. 1995. A combined biological and enzymatic amplification (BIO-PCR) technique to detect Pseudomonas syringae pv. phaseolicola in bean seed extracts. Phytopathology 85:243-248.

27. Shivalingaiah, Sharanaiah, U., and Mysore, K. S. 2012. Detection of Xanthomonas oryzae pv. oryzae in rice seeds by molecular techniques. Asian and Austral. J. Plant Sci. Biotechnol. 6:44-47.

28. Soto-Suárez, M., González, C., Piégu, B., Tohme, J., and Verdier, V. 2010. Genomic comparison between Xanthomonas oryzae pv. oryzae and Xanthomonas oryzae pv. oryzicola using suppression-subtractive hybridization. FEMS Microbiol. Lett. 308:16-23.

29. Sulzinski, M. A., Moorman, G. W., Schlagnhaufer, B., and Romaine, C. P. 1996. Characteristics of a PCR-based assay for in planta detection of Xanthomonas campestris pv. pelargonii. J. Phytopathol. 144:393398.

30. Swings, J., Van den Mooter, M., Vauterin, L., Hoste, B., Gillis, M., Mew, T. W., and Kersters, K. 1990. Reclassification of the causal agents of bacterial blight (Xanthomonas campestris pv. oryzae) and bacterial leaf streak (Xanthomonas campestris pv. oryzicola) of rice as pathovars of Xanthomonas oryzae (ex Ishiyama, 1922) sp. nov., nom. rev. Int. J. Syst. Bacteriol. 40:309-311.

31. Szemes, M., Bonant, P., Weerdt, M. D., Baner, J., Landegren, U., and Schoen, C. D. 2005. Diagnostic application of padlock probes-multiplex detection of plant pathogens using universal microarrays. Nucleic Acids Res. 33:e70.

32. Templeton, K. E., Scheltinga, S. A., Beersma, M. F., Kroes, A. C., and Claas, E. C. 2004. Rapid and sensitive method using multiplex real-time PCR for diagnosis of infections by influenza a and influenza B viruses, respiratory syncytial virus, and parainfluenza viruses $1,2,3$, and 4 . J. Clin. Microbiol. 42:1564-1569.

33. Tian, Y., Zhao, Y., Bai, S., Walcott, R. R., Hu, B., and Liu, F. 2013. Reliable and sensitive detection of Acidovorax citrulli in cucurbit seed using a padlock-probe-based assay. Plant Dis. 97:961-966.

34. Tsui, C. K., Wang, B., Khadempour, L., Alamouti, S. M., Bohlmann, J., Murray, B. W., and Hamelin, R. C. 2010. Rapid identification and detection of pine pathogenic fungi associated with mountain pine beetles by padlock probes. J. Microbiol. Methods 83:26-33.

35. Van Doorn, R., Slawiak, M., Szemes, M., Dullemans, A. M., Bonants, P., Kowalchuk, G. A., and Schoen, C. D. 2009. Robust detection and identification of multiple oomycetes and fungi in environmental samples by using a novel cleavable padlock probe-based ligation detection assay. Appl. Environ. Microbiol. 75:4185-4193.

36. Walcott, R. R., and Gitaitis, R. D. 2000. Detection of Acidovorax avenae subsp. citrulli in watermelon seed using immunomagnetic separation and the polymerase chain reaction. Plant Dis. 84:470-474. 
37. Weisburg, W. G., Barns, S. M., Pelletier, D. A., and Lane, D. J. 1991.16S ribosomal DNA amplification for phylogenetic study. J. Bacteriol. 173:697-703.

38. Wonni, I., Ouedraogo, L., and Verdier, V. 2011. First report of bacterial leaf streak caused by Xanthomonas oryzae pv. oryzicola on rice in Burkina Faso. Plant Dis. 95:72.

39. Xu, W., Bai, W., Luo, Y., Yuan, Y., Zhang, W., Guo, X., and Huang, K.2008. A novel common single primer multiplex polymerase chain reaction (CSP-M-PCR) method for the identification of animal species in minced meat. J. Sci. Food 88:2631-2637.

40. Zhang, H., Hu, B., and Liu, F. 2007. Development of duplex PCR assay for detection of Xanthomonas oryzae pv. oryzae and X. oryzae pv. oryzicola. Plant Quarantine (China) 21:34-35.

41. Zhao, W., Zhu, S., Liao, X., Chen, H., and Tan, T. 2007. Detection of Xanthomonas oryzae pv. oryzae in seeds using a specific TaqMan probe. Mol. Biotechnol. 35:119-127. 